\title{
THE Voice OF AN INDiAn Trans WoMAN: A HiJRA AUTOBIOGRAPHY ${ }^{1}$
}

\author{
REGIANE CORRÊA DE OLIVEIRA RAMOS \\ Faculdade de Tecnologia (Fatec), Brazil \\ regianecorreadeoliveira@gmail.com
}

Received: 19-01-2018

Accepted: 12-03-2018

\begin{abstract}
The aim of this paper is to raise awareness of the humanity of hijras through their autobiographies. The Truth about Me: A Hijra Life Story (2015) by A. Revathi will shed light on transsexuality in India. The hijra literature in English is gaining space, albeit small, in the literary milieu with its main character, a trans woman, who narrates her story challenging the heteronormative world. Not bending to gender norms, Revathi sought her place in the world, becoming not only a hijra, but also a political agent in her community. Her writing/telling reveals the bruises and wounds of a body violated by a deeply hierarchical society and her activism evidences that trans people are not passive recipients of forces acting upon their lives. They deploy agency in a variety of ways showing how their lives are located at the intersection of caste, class and patriarchies. These structures along with heteronormativity not only oppress them but also make them invisible under the heterosexual, family and reproductive model. In order to understand the hijras communities, it is important to analyze this through the intersectionality of social markers--gender, sexuality, class, caste, generation, region, religion, kinship and etc--interacting them at multiple and often simultaneous levels (Reddy 2005). Moreover, one must think of the terms izzat (honour) and asli (authenticity) that permeate Indian culture.
\end{abstract}

KEYWORDS: Transsexuality; hijra literature; Indian culture, gender violence

RESUMEN: La voz de una mujer india trans: la autobiografía de una hijra

El objetivo de este artículo es crear conciencia acerca de la humanidad de las hijras a través de sus trabajos autobiográficos y más concretamente en The Truth about Me: A Hijra Life Story (2015) de A. Revathi. La literatura sobre las hijras está conquistando espacios, aunque aún de dimensiones reducidas, en el panorama literario indio, poniendo en el centro de la narración a una persona que, aun habiendo nacido hombre, se identifica con las características tradicionalmente atribuidas a las mujeres. El personaje narra su historia como hijra, personas del tercer género a las que tradicionalmente se les atribuyen características masculinas y femeninas. En la India medieval constituían una comunidad aceptada hasta que fueron relegadas a los márgenes de la sociedad con la dominación colonial, problematizando la heteronormatividad hegemónica que reduce a las personas en clasificaciones de corte binario del tipo masculino-femenino. Sin plegarse a las normas de género o

\footnotetext{
${ }^{1}$ This paper was presented in the 5th International Conference of the Spanish Association for Interdisciplinary India Studies Writing/Righting Wrongs: Misrepresentation, Discrimination, Inequality at the Autonomous University of Barcelona, Barcelona - Spain (1 December 2017).
} 
ante las tradiciones estrictas de la sociedad india, Revathi buscaba su lugar en el mundo y se convirtió no solo en una hijra, sino también en una activista política para su comunidad. Su obra muestra los golpes y heridas de un cuerpo violado por una sociedad patriarcal fundamentada en castas. Escribir/contar su historia le da visibilidad, a pesar de los muchos factores sociales que la invisibilizan. Para comprender la comunidad de las hijras, a la que Revathi pertenece, es importante observarla desde la interseccionalidad de marcadores sociales, como son el género, la sexualidad, la clase, la casta, la generación, la región, la religión y las relaciones familiares, etc., interactuando a varios niveles y, a menudo, simultáneamente (Reddy, 2005: 32-33). Además, en el contexto de las hijras, se tienen que tener en cuenta términos como izzat (honor) y asli (auténtico) que impregnan la cultura india. Al igual que Revathi, y muchas otras hijras, pretendo narrar sus vidas y desearía que fueran respetadas al igual que cualquier otro ser humano sin importar el género y que sea reconocido como un género real y auténtico.

PALABRAs Clave: Transexualidad, literatura hijra, cultura india, violencia de género

In India, Ardhanareeswara, the half-male and half-female form of Shiva, is worshipped. Why then would such a country abuse hijras? A. Revathi (2016: x)

\section{Challenging the Social, Historical and Legal Definition of 'hijra'}

Indian culture has a historically marked tolerance as regards androgynous appearance. $^{2}$ The writer Devdutt Pattanaik, for example, uses examples of mythical characters such as Shikhandi to argue that Hinduism was tolerant of, and even celebrated, the use of the modern term, "queerness". However, this tolerance is not displayed towards hijras, defined as female-identified persons assigned male at birth. In modern India, hijras have lived on the fringes of society, often begging at traffic lights, ${ }^{3}$ living in poor areas, indulging in petty crimes to survive and, by and large, experiencing multiple forms of violence from society at large as well as from the state. They are frequently subjected to harassment by the police, whose discriminatory and inhuman acts are legitimized by law and social intolerance. In A Life in Trans Activism (2016), for example, A. Revathi (2010) notes that, "We are harassed by parents, teachers, peers, and the police. The media and law only highlight our

\footnotetext{
${ }^{2}$ It is important to highlight that hijras refers not only to Hindu mythology but also to Muslim historical narratives, creating a syncretic culture which respects Islam within the hijra community. In With Respect to Sex: Negotiating Hijra Identity in South India, Gayatri Reddy points out that hijras in Secunderabad cross religious borders and adopt both Hindu and Muslim rituals. As she exemplifies, "While they employed Muslim comensal, sartorial, purification, and burial customs, they simultaneously worshipped a Hindu goddess through whom they derived their divine power to confer fertility and thus obtained social legitimacy" (Reddy, 2005: 111).

${ }^{3}$ In 2014, a two-minute video, The Seatbelt Crew, was created to promote road safety and help foster a more positive public image of hijras. However, the advertising campaign reinforced the stereotyped image that their place is on the streets and at street lights. For further information, see: https://www.youtube.com/watch?v=muCU6_Y_Kyo.
} 
involvement in street based sex work and begging. Why don't you highlight some of our pressing needs and concerns and the multiple violations and oppressions we experience?" (62).

There is, no doubt, a stigma attached to transsexuality and transgender people (here I include local terms of reference such as hijra, thirunangai, kinnar, mangalamukhi, aravani, kothi, jogappas, shiv shaktis, thirunambis, bhaiyya, and paiyyan) in India. ${ }^{4}$ They face widespread discrimination and have their human rights violated on a daily basis, and for years the medical community has pathologized being transgender, imposing on transgender people the so-called diagnosis of "gender identity disorder." At present, the medical community affirms that transgender people suffer from "dysphoria," that is, that they are afflicted with discomfort with their bodies. However, despite their struggle against these mental health labels such as Diagnostic and Statistical Manual of Mental Disorders -DSM), and despite questions of class, caste, race, gender, and patriarchy, hijras are writing their own narratives using autobiographies as an antidote to all forms of discrimination. In these narratives, the hijras write about their experiences of constant harassment, the looks of disapproval, the fear of being in public spaces, the fear of not returning home alive, the fear of using the public toilet, the fear of going to school, the fear of being arrested and, as Revathi strongly emphasizes, "fear of everything and anything" (Revathi, 2010: ix). But now, this marginalized group is overcoming its fears and has started to speak up to the world, refusing to accept the invisibility imposed on its existence. They are asserting that being transgender is an identity, not a disorder. By publicly assuming their gender identity, they are challenging the heteronormative discourses that have imprisoned them for ages for being the deviants (Foucault, 1988: 43). They are inscribing themselves in world history, showing how they apprehend everything that exists within the norms and beyond them.

Hijra literature, a new and evolving literary genre in India, is trying to make people aware and, as Revathi argues, "hijras are capable of more than just begging and sex work" (Revathi, 2010: v). As Dhrubo Joyoti reminds us, the autobiographies by transgender women, such as A. Revathi and Living Smile Vidya, have added to our understanding of the

\footnotetext{
${ }^{4}$ The United Nations Development Programme (UNDP) India adds to its report, Hijras/Transgender Women in India: HIV, Human Rights and Social Exclusion, a glossary explaining these gender identities. For further reference, see:

http://www.undp.org/content/dam/india/docs/hijras_transgender_in_india_hiv_human_rights_and_social_exclus ion.pdf
} 
complexities of caste, gender and sexuality. They are a compilation of the history and culture of the hijras and their opposition to the dominance of modern knowledge systems which create insidious processes of stigmatization, discrimination, marginalization, pathologization and confinement, operating at the level of social perception, social space, social institutions, common sense, judicial system, family, state and medical system (Foucault, 1988: 80-81). The genre is also trying to raise public awareness about gender and sexuality and to discuss human rights, democracy and equality in Indian society. Despite the social exclusion they face, the hijras have dared to live transgressively in relation to social norms and their lives were and are marked by unique forms of resistance. No experience of gender is so strong in the sense of denaturalizing what it is to be a man and what it is to be a woman than the trans experience. They deploy agency in a variety of ways by showing how their lives are located at the intersection of caste, class and patriarchies.

Silence, one of the strongest forms of exclusion of the hijras, has been broken and their narratives are now fighting transphobia, as Living Smile Vidya talks about, "a type of brahmanism with the hijra becoming the untouchable subject" (qtd in Semmalar, 287). The trans activist Gee Imaan Semmalar explains that trans people are able to rent out houses only in Dalit settlements. The "solidarity" of the Dalits, as Semmalar observes, is not based on the recognition of their gender identity, but on the economic need of those who have to rent their houses (Semmalar, 2014: 287). The discrimination on the grounds of gender identity and sexual orientation, which Semmalar highlights, was felt, for example, by some of the twentyone transgenders hired by the Kochi Metro Rail in 2017. Eight of them had to quit their jobs as nobody was willing to rent out house/rooms to them. ${ }^{5}$

I shall now focus on hijra literature within the context of gender-specific violence through excerpts from The Truth about Me: A Hijra Life Story (2010) by A. Revathi. For this purpose, I am going to use the definitions given by hijras to themselves in their autobiographies and interviews to describe the community and their gender identity. To just listen to the transgender people talk about their trajectory is to give visibility to their struggle. I would like the narrative of Revathi to have a dialogue with other narratives of the transgender people who are writing autobiographies and establishing themselves in the literary space, that, no doubt, has been predominantly white and male. It is important to

\footnotetext{
${ }^{5}$ For detailed information of the case, access https://scroll.in/latest/841693/eight-transgender-employees-quitworking-for-kochi-metro-within-a-week-of-its-launch.
} 
consider hijra literature or "trans literature" as a possible literary production that fundamentally questions the representation of hijras in ancient texts, in medieval references, and in colonial literature. As Ngũgĩ wa Thiong'o has argued, we have to look for "globalectic reading of literature and organization of literatures". For him, "globalectics assumes the interconnectedness of time and space in the area of human thought and action". (Thiong'o, 2013: 41).

\section{Transsexuality}

In this section, I will follow the theoretical approach that asserts that there is neither a universal transsexual nor a real transsexual. Berenice Bento's books A Reinvenção do Corpo: Sexualidade e Gênero na Experiência Transexual (2006) and Transviad@s gênero, sexualidade e direitos humanos (2017a) will shed light on the plurality of bodies:

pre-operated, with hormones, waxed, retouched, with silicone, and with makeup. Bodies included, undone and redone, living archives of histories of exclusion. Bodies that blur the boundaries between the natural and the artificial, between the real and the fictitious, and which denounce, implicitly or explicitly, that gender norms are not able to achieve an absolute consensus in social life. (my translation) ${ }^{6}$

pré-operados, hormonizados, depilados, retocados, siliconados, maquiados. Corpos inclusos, desfeitos e refeitos, arquivos vivos de histórias de exclusão. Corpos que embaralham as fronteiras entre o natural e o artificial, entre o real e o fictício, e que denunciam, implícita ou explicitamente, que as normas de gênero não conseguem um consenso absoluto na vida social. (Bento, 2006: 19-20)

Bento's Ph.D. thesis, which gave rise to the book A Reinvenção do Corpo: Sexualidade e Gênero na Experiência Transexual (2006), was the first research on depathologization of trans identity in Brazil. The Brazilian sociologist, Bento, dialoguing with Michel Foucault, employs the term of the dispositif of transsexuality to talk about the discursive mechanisms that produce the truth about what it is to be transsexual. Within the dispositif of transsexuality, Bento identifies two discourses: the discourse of psychoanalysis and the discourse of endocrinology. According to Bento, both of them claim that the transsexual is the person who hates his/her genitals and seeks sex reassignment surgery to

\footnotetext{
${ }^{6}$ For this paper, I have translated into English all the quotations of Bento's work. As readers may not be familiar with Portuguese, I reversed the order of placing the translation in the text (translation/original) following MLA.
} 
live his or her heterosexuality. Disagreeing with this statement, she affirms that transsexuality has nothing to do with sexuality, as some want the surgery and others do not. She carries on arguing that the central issue that permeates the discourse of transsexual people is the demand for the recognition of gender identity and for the change of documents. Each trans person lives his or her sexuality differently and Bento contends that there is a plurality of sexual experiences in transsexuality and there is a quest for the recognition of another gender.

Bento upholds the depathologization of trans identities and states that,

to discuss transsexuality makes us discuss gender identity separated from biology because they are people who have normal genitals, all normal biological structure, absolutely normal chromosomes and yet do not recognize themselves in their body. (my translation)

discutir transexualidade nos remete a discutir identidade de gênero deslocada da biologia, porque são pessoas que têm todas as genitálias normais, toda a estrutura biológica, cromossomos absolutamente normais e, no entanto, não se reconhecem no corpo (Bento, 2017a: 107)

If trans experience is pathologized, as some psychologists, psychiatrists and psychoanalysts tend to sustain, transsexuality will, as Bento urges, consequently follow the path of universalization, where models can be reproduced in all places of the world. When it is depathologized, as Bento argues, the notions of masculinity and femininity will be rid of any biological reference (Bento, 2017a). In this manner, it is one thing to be a transsexual in Brazil and another in India or in Spain. In this light, the trans subject is a transgressor of the regulating apparatus of gender norms and these identities are constructed within language and discourse (Butler, 2012). Gender, as Judith Butler affirms, is performative (Butler, 2012: 185). It is related to performance, practice and social recognition.

In the Indian context, hijras are fighting to be socially recognized by deploying, as Aniruddha Dutta \& Raina Roy assert, "various unruly changeable practices of identification and citizenship arising from complex strategies of survival and self-assertion in societies that have not provided them with stable options rather than from any abstract radical politics" (Dutta \& Roy, 2014: 333). In their autobiographies, hijras are writing about the transgender experience in India. They are also deploying counter-hegemonic narratives to dismantle the cartographies of trans identities (stable, singular trans identity), and are pointing out, to use Dutta \& Raina's (2014) words, the "class/caste/racial hierarchies that they are embedded in" (335), which marginalize them. These narratives also describe the many forms of gender/sexual variance found in India. 
In an interview with the magazine Guernica, Laxmi Narayan Tripathi, one of the most famous hijra activists in India, explains what a hijra is in India:

a hijra is [someone who has transitioned from] male to female, but we don't consider ourselves female because culturally we belong to a completely different section of society. Many hijras are castrated, but it's not compulsory. They say it's the soul which is hijra. We feel we are neither man nor woman, but we enjoy femininity. I enjoy womanhood, but I am not a woman. It's very confusing. (Tripathi, 2015b)

This sense of confusion in terms of belonging arises because hijras distinguish themselves from the hegemonic patterns of masculinity and femininity (what it is to be a man or a woman), thus singling out the division between the affective register of community (local term) and the language of political representation or identity. Furthermore, as Dutta \& Roy observe, some subjects, who do not have access to modern methods of transitioning, have thought up trajectories of sartorial, bodily, or behavioral feminization which do not identify with womanhood (Dutta \& Roy, 2014). Others, like Laxmi Tripathi, do not want to pass as a woman. However, the above statement indicates that self-identifications matter. They are not fixed and nor are they essentialized identities.

The term hijra is a social construct and not a biological fact. According to Laxmi Tripathi (2015), the word "hijra" derives from the Urdu word "hijar". A hijar is a person who has walked out of his tribe or community. Thus, a hijra is someone who has left the mainstream society, comprising men and women, and joined a community of hijras" (Tripathi, 2015: 171). The hijra, as a gender identity, is related to a community and it is the oldest ethnic-transgender community in India. The community is a complex social structure called jamaat. Devoid of traditional kinship ties, the hijras living in a jamaat develop alternate forms of relationships based on the common experience of a life outside the socially prescribed norms and models. They provide comfort, support and a sense of belonging to one another in the social group. A. Revathi describes the community as, "similar to an extended family and, like a household, is headed by an elder known as the guru who in turn adopts a set of chelas or disciples who are like daughters to her. [...], the jamaat becomes their life and security" (Revathi, 2010: 127). The hijra community has its own culture, its own religious beliefs, its own rituals and its own language (secret/coded language). Organized 
matrilineally, its strength lies in the kinship ${ }^{7}$ relationship of the guru-chela system, which is based on social and economic obligations between the master (guru) and the disciple (chela/hijra). The community functions as a shelter for trans women excluded from the "cistem" and also as a space for subversion of those gender norms imposed by a heteronormative discourse. To better understand this, it is best to think and analyze the term in the plural "communities" of hijras, taking into account the regional, linguistic, cultural, religious, economic and caste differences in the Indian subcontinent.

A person is not born hijra but becomes so through a ritual known as reet, which is a difficult and complicated rite of passage. The reet marks, as Gayatri Reddy (2005) highlights, "the authenticity and commitment to hijra identity" (Reddy, 2005: 154). In this ritual, the initiated chooses a guru and the guru gives money to this chela (disciple), thus establishing a social and economic contract between the two. The chela receives a sari (the color might vary according to the gharana or school), a dupatta, and training on how to clap, how to beg and how to flatter people with their talk and gestures. As part of a group, a hijra uses this training to earn a living. In "Not This, Not That: The Hijras of India and the Cultural Politics of Sexuality (2005)," Vinay Lal explains that

At what are traditionally held to be the two most auspicious moments in an adult person's life in India, namely, marriage and the birth of a male child, hijras come into their own as persons possessed of the power of conferring blessings and, complementarily, inflicting curses. (Lal, 2005: 123)

There are three main forms for hijras to make a living: badhaai (giving blessings on auspicious occasions) and mangti (begging and threatening with curses when refused) or to get involved in dhandha (sex work), as society does not offer them jobs and other opportunities. Because of lack of education (they are forced to quit school because of gender violence) and job opportunities (most doors are shut to them) many hijras are forced, as Laxmi affirms, "to find refuge in the hijra world" (Laxmi, 2016: 8).

\footnotetext{
${ }^{7}$ The Indian anthropologist Gayatri Reddy remarks that hijra kinship arrangements subvert the ideal formulation of kinship as it does not admit marital obligations, does not have procreative ideologies and does not follow the logic of caste system. These social arrangements can be related to those of devadasis and twa'ifs communities, groups, as she contends, "that challenge the 'respectability' of marriage, explicitly or implicitly subvert gender roles, and encode an intricate guru-sisya parampara (teacher-disciple tradition) and household structure" (146).
} 


\section{Third Gender and a New but Inadequate Definition}

On April 15, 2014, in a landmark judgment, India's Supreme Court recognized transgender people as a third gender. Delivering the verdict, Justice K.S. Panicker Radhakrishnan asserted that "recognition of transgenders as a third gender is not a social or medical issue but a human rights issue"(Radhakrishnan, 2014). However, we know that a law does not mean that the rights of transgender people will be respected. Also a law does not guarantee that the mentality of people will be transformed overnight. After two years of passing The Rights of Transgender Persons Bill, 2014 by parliament, Indian trans people are still fighting for their rights, and the Central and state governments have still not implemented some of the core directions given in the judgment, as pointed out by Vyjayanti Vasanta Mogli in an article in The Wire:

Access to education and consequently to employment continue to evade the transgender community. Transpeople continue to face the violation of their right to life, facing unreported and unregistered hate crimes. There is very poor access to health and medical care, and many transpeople continue to be pathologised as having 'gender identity disorder' due to inaction by the Medical Council of India. (Mogli, 2016)

To make it more complicated, transsexuals, activists, academics and lawyers have questioned the definition of the term transgender in the "Transgender Persons (Protection of Rights) Bill, 2016". The bill defines (i) "transgender person" as someone who is:

(A) neither wholly female nor wholly male; or (B) a combination of female or male; or (C) neither female nor male; and whose sense of gender does not match with the gender assigned to that person at the time of birth, and includes trans-men and transwomen, persons with intersex variations and gender-queers. (Transgender Persons Bill, 2016)

Sangama, an NGO for Sexual Minorities, and Reach Law filed a case for an amendment to be made in the definition, claiming that "Transgender Persons (Protection of Rights) Bill, 2016" completely distorts the historical legislation for transgender in India. For them, this definition is improper and derogatory, violating human rights, as it inhibits people from expressing their gender identity. In A Life in Trans Activism (2016), A. Revathi argues that 
Apart from me, several of my transgender community people (that also includes trans men), have considerable reservations and confusion about the implications of the judgment. The most important question that comes out to our minds is this: What is meant by the term transgender? What is meant by the term third gender? Who is included? Who is left out? (Revathi, 2016: 230)

In "Outlawed: The Supreme Court judgment on third gender and its implications" Gee Imaan Semmalar (2014) not only interrogates who the judgment includes or excludes in its understanding of transgender ${ }^{8}$ but also raises an important question about the Other Backward Classes reservations for a community that has among them a large number of Dalit trans people. The implication is, as Living Smile Vidya highlights to Semmalar, "putting transgenders under an oppressed caste category erases the caste privilege that savanna [upper caste] transgenders have" (Semmalar, 2014). The trans people demand caste and gender reservation once it will give representation to Dalit women and Dalit transgender as well.

According to the officials, a revised bill that is back in Parliament, will drop "neither wholly female nor wholly male" from the definition. The certificate of identity as a transgender person will be issued by the district magistrate indicating a change in gender on receipt of applications after being satisfied, suggesting that medical screening would not be required. The transgender person will have the option to choose man, woman or transgender independently of surgery or hormone therapy. What seems progressive in this revised bill is the comprehensive insurance scheme that will cover sex reassignment surgery, hormonal therapy and laser therapy. It is unclear if the revised bill will address the issue of reservation for transgender. For the activists, the bill should define discrimination and punishment for sexual violence against trans people.

\section{Hijra Autography as a Means of Showing Sexual Fluidity}

In mythical Hindu narratives, there is evidence of gender fluidity, and texts such as the Vedas, epics like the Mahabharata and the Ramayana, the Puranas and other regional folklore, we can find mythological characters or deities whose behavior can be interpreted as

\footnotetext{
${ }^{8}$ In "Decolonizing Transgender in India", Aniruddha Dutta and Raina Roy question the universalizing transgender category, as it does not take into consideration the different regional gender/sexual variance. For them, "variant imaginations of scale are crucial to challenge these colonizing implications of the transgender category, such that local or regional discourses are not compelled to be legible terms of globalizing understanding of gender, and the latter also become accountable to the former" (335).
} 
those of lesbians, homosexuals, bisexuals and transgenders. They, as Ruth Vanita and Saleem Kidwai (2008) and many others have pointed out, do not explicitly speak of homosexuality, but portray gender change, homoerotic encounters, and intersex or transgender characters. Deities change gender, assume androgynous forms and manifest themselves in different avatars. In contemporary literature, mainly in the hijra literature, transgenders are narrating their own stories and are depicting what have been silenced in these previous narratives, for example, gender violence, discrimination, and the transitioning process.

In the aftermath of Me Hijra, Me Laxmi, R. Raj Rao (2015), considered one of the best-known gay rights activists in India and a pioneer in Indian queer literature, argues that hijra literature cannot be read in isolation as a single production. It, according to Rao, should be read along with Indian gay and lesbian literature that has boomed in recent years with novels, short stories, poems and autobiographical accounts. There are many such voices and the list is quite long, but all come out as a counter-narrative against the heterogeneous cultural hegemony in different dimensions. In addition, these voices demand the repeal of Section 377. Chapter XVI, Section 377 of the Indian Penal Code dating back to 1861, introduced during the British rule of India, criminalizes sexual activities "against the order of nature", arguably including homosexual sexual activities. This law has been used by the police to intimidate sexual minorities and has been a source of serious violations of human rights, especially for hijras. There are numerous stories about transgenders that were charged and threatened with Section 377. They are dumped in police vans and whisked off. Sometimes they are thrown into jail.

In 'Disrupting the Dinner Table: Re-thinking the 'Queer Movement' in Contemporary India," Ashley Tellis (2012) criticizes this campaign against the Delhi High Court Judgment on Section 377 and contents that the queer movement in India, which is articulating the protests, "is classist, casteist, sexist and complicit with power structures of the most oppressive kind" (Tellis, 2012: 143). Tellis claims that many marginalized groups (mainly hijras) were not asked to participate in the elaborations to present an agenda with their demands. He writes that this "evacuate[s] them of all agency in the interest of portraying them as human rights victims" (153). ${ }^{9}$ It is interesting to note that although Tellis, among

\footnotetext{
${ }^{9}$ For further reading, see Jason Keith Fernandes who criticizes the Indian LGBT movement where, "a certain upper-class agenda was being articulated, while adopting a subaltern image of the transgendered (hijra) Indian
} 
others like Oishik Sircar and Jason Keith Fernandes, provides a detailed critique of the Indian LGBT elite discourse and advocates for the rights of hijras, he does not mention in his article the rise of hijra literature and the importance of their autobiographies, as a device which refers to the ability of the subjects to initiate action in engaging or resisting all forms of power.

For me, the enormous potential of this writing is that it conjures up the four enunciative discourses: (1) who is speaking? the hijras; (2) From what site are they speaking? from a marginalized group (3) Why do they speak? to have their rights recognized by law (4) To whom do they speak? to a world which rejects them and dispossesses them of humanity (Foucault, 1995: 56-61). The writing, as Bento (2017b) refers to the autobiography of Jõao Nery, ${ }^{10}$ "helps us cross the agonies of our souls, a possibility to cure the bruises and internal wounds. Beyond this therapeutic dimension, writing immortalizes events" (Bento, 2017b: 21). ${ }^{11}$ When the hijras use this powerful instrument, it is because they are sure that writing will make their story circulate as a political act. It shows that they refuse to live a clandestine life. They refuse to remain invisible and come to the public sphere to tell their stories. So it is time for us to look at their productions and understand their engagement to overcome the layers of oppressions that exclude them from history.

Naan Vidya (2007) ${ }^{12}$ by Living Smile Vidya, the first autobiographical account of a hijra, was written in Tamil and then translated into seven other languages. Vidya's autobiography comes to Indian bookstores to challenge the logic of heteronormative system, which marginalizes gender identities that do not comply with the heterosexual, family, and reproductive model. According to Nivedita Menon, "In India too, there was a polyvalence of gender identities and sexual desire even up to the nineteenth century, which was closed off in a variety of ways, through legal and social interventions that disciplined a range of nonnormative sexualities and family arrangements" (Menon, 2012: 96). However, Semmalar (2017) argues that the disempowerment of the trans community in India is the result of many

as symbol of the movement". Fernandes, Jason Keith (2009). "The Dilemma after the Decision: Strays thoughts after Gay Liberation”, available at http://www.tehelka.com/story_main42. asp? lename=Ws220809 The_Dilemma.asp.

${ }^{10}$ João Nery is the first Brazilian trans man to write an autobiography.

${ }^{11}$ In the original, "a escrita nos ajuda a atravessar as agonias de nossas almas, uma possibilidade de cura para os hematomas e feridas internas. Para além dessa dimensão terapêutica, a escrita imortaliza os acontecimentos" (21).

${ }^{12}$ I am Vidya: A Transgender's Journey (2007) is the title in English. 
factors, mainly the caste system, patriarchy, transphobia, lack of awareness, and public prejudices, etc.

With her writing, Vidya paved the way for Revathi, Laxmi, Manobi and many others to tell their stories as well and denounce the dehumanizing living conditions of hijras, with no rights as citizens. A. Revathi is the author of three books The Truth about Me: A Hijra Life Story (2010), Our Lives Our Words: Telling Aravani Life Stories (2012) and A Life in Trans activism (2016); Laxmi Tripathi launched Me Hijra, Me Laxmi in 2015 and then Red Lipstick in 2016, while Manobi Bandyopadhyay published the Gift of Goddess Lakshmi in 2017. These works were originally written in Tamil (Vidya and Revathi), Marathi (Laxmi) and Bengali (Manobi) and translated into English, a language which provides greater visibility and international reach. This offers a possibility for the hijras' situation to be known and discussed within and outside India. The translation into English contributes to the empowerment of the marginalized groups such as women, Dalits, tribals, and other minorities. Furthermore, it also allowed me to have contact with this literary genre and to devote myself to its study.

Like India, in Brazil, João Nery, Jordhan Lessa and Amara Moura, among other trans people, are publishing their experiences of transmasculinity and transfemininity and are raising the question about trans-identities. I see that the Brazilians, like Vidya, are encouraging the trans subject to talk about their identity conflicts, gender violence and overcoming these obstacles. These authors are taking a step further and bringing the trans subject to the center of the narrative. It is important to remember that trans women and trans men have always, as Bento (2017a) reminds us, existed on the streets, 'reconstructing their bodies and producing meanings for the relationship among body, sexuality, gender and subjectivity, but they were invisible and made invisible' "reconstruindo seus corpos, produzindo sentidos orginais para a relação enter corpo, sexualidade, gênero e subjetividade, mas eram invisíveis e invisibilizadas" (Bento, 2017a: 47). They were and are seen as dispossessed of humanity as trans people are extremely vulnerable and dehumanized anywhere in the world.

The autobiographical genre not only reflects the individual's desire to tell her own life experience, but serves as a device to sensitize society about, as Revathi writes in her autobiography, "my daily experience of discrimination, ridicule and pain; it is also to speak about my resistance and my joys" (Revanti, 2010: v). Used as a political agent, it brings the 
excluded and/or the marginalized to the center of the narrative, articulating gender and sexuality in the fight for human rights. It is a text that speaks about abject bodies, that is, bodies without social intelligibility. The great difference between autobiography and anthropological narrative lies precisely in the ability of the former to arouse empathy and to present the hijra/trans person as an individual who has dreams, desires and fears like any other human being. Through it, Revathi makes her voice loud. She overturns the system which normally gives voice to the other, describes the other, and represents the other in the scientific writing. She makes a plea for equality and human rights for transgender people. She talks about myths and misconceptions about gender and sexuality. She demands "acceptance from parents, from society, from the world to be human to live as we have chosen" (2016: 68). It is a very sensitive writing which denounces physical and verbal aggression; discrimination and violations of human rights.

\section{Painful Bodies: Archives of Inhumane Acts}

Truth about Me: A Hijra Life Story (2010) is the story of A. Revathi, a femaleidentified person who was assigned as male at birth. Revathi portrays, in various stages, her transition from male to female and her identification with the hijra community. To listen to the trans people and let them tell their life trajectory is to give visibility to the struggle of the transsexuals. It can be seen in Revathi's narrative, and in most trans reports, how the trans body is marked/beaten verbally and physically:

At school, I felt fear looking at the big boys, those in Classes 11 and 12. And they were always on the lookout for me. They had marked me out from the others. Whenever I walked past them on the school grounds, they would yell, 'Hey girl-boy' and hit me on the head with their balled-up fists. They would pinch me on my chest, and taunt me saying, 'When you played Chandramathi, what did you stuff your chest with?' On the days this happened, I did not want to sit next to the boys in my class, for I felt coy and shy. (Truth about Me, 9)

To perform Chandramathi, a woman character in the play Harishchandra was to Revathi, still a child of twelve, a moment to experience/live all that she was feeling in childhood: “A woman trapped in a man's body was who I felt of myself” (15). Proud of herself, she describes: "I think I did this exceptionally well, because everyone praised me saying that I looked and acted like a real woman. This pleased me very much" (9). In the 
above excerpt, it can be perceived that Revathi's joy at living out her gender identity is destroyed by the bullying by older boys. They made fun of her for not having breasts. A school is one of the most violent spaces for children who do not behave according to heterosexual conventions. The reiteration of verbal and physical aggression against feminine boys and masculine girls overturns any illusion that heterosexuality is natural.

Gender violence against Revathi also occurs in the family space. When she returns home, after fleeing to New Delhi and initiating in the hijra community, she recalls the reaction of her brother, who:

shut the door, grabbed a cricket bat, and began hitting me, all the while screaming. 'That'll teach you to go with those Number 9s. Let's see you wear sari again, or dance, you mother-fucking pottai!' He beat me hard mindlessly, yelling that he wanted to kill me, I who had dared to run away. I tried to protect my face and head with my hands to keep the blows from falling. But nevertheless they came down hard, and I felt my hands swell. I was beaten on my legs, on my back, and finally my brother brought the bat down heavily on my head. My skull cracked and there was blood all over, flowing warm. 'That's right. Beat him and break his bones. Only then will he stay at home and not run away,' I heard my mother say. (Truth about Me, 55)

In India, the concept of honor (izzat) serves, as Uma Chakrabarti (2013) underlines, "as a link between the behaviour of an individual woman and the idealized norms of the community. By constantly evoking the twin notions of honour and dishonour, families either condition or shame women into appropriate and inappropriate behaviour" (Chakrabarti, 2013: 151). It can be inferred from the excerpt above that Revathi is dishonoring her family by being a hijra. Thus her brother and mother believe that she deserves this punishment, that is, a cure therapy, which refers to any form of treatment which aims to stop same-sex attraction or to suppress a person's gender identity.

In addition to these verbal and physical aggressions, Revathi suffers psychological violence by having her hair cut by her brother. According to community standards, the hijra must keep her hair long, otherwise she will be penalized. Forced to erase this feminine symbol brutally, Revathi says: "At the temple, when my hair was shorn off I felt more pain than I did when my brother thrashed me" (57). The vulnerability of the hijras is greater in the world of prostitution, where they are raped by both the goondas (rowdies) and the police:

I felt trapped and not knowing what to do, I had to accede to his demands. I held onto his legs and pleaded when he wanted me to do things that I did not like doing ( $\mathrm{He}$ 
wanted me to have anal sex with him.) He spat abuse at me and forced me into the act. When I screamed in pain and yelled for my guru, he shut my mouth with one of his hands, whipped out a knife with the other and threatened to take it to my throat. I was hurting all over, and yet had to give in and do as he told me. The skin down there felt abraded and I was bleeding. Unmindful, he left, but only after he had snatched my purse away from me. Men like him will understand the terror and pain they cause only if they become hijras and are hurt by rowdy men such as themselves. (Truth about Me, 108)

For hijras, violence remains an all-pervasive phenomenon. In most cases, clients are the top perpetrators of physical and sexual violence, followed by strangers, boyfriends and partners. The violence that her body suffered for so many years, among other reasons, motivates Revathi to take a stand and fight for her rights and the rights of sexual minorities in India. She has been devoting herself to trans subjects since the year 2000 with the certainty that these individuals need to have their place in society and their bodies and rights respected. A striking feature of her work is the struggle for making Indian transmen visible, who are in a situation of more vulnerability than transwomen, as they live in obscurity and silence and are more stigmatized and do not count on the support of the feminist movements. In addition, she also focuses her attention on non-English speaking sexual minorities who have less access to information and are more discriminated compared to English-speaking gays and lesbians. Revathi claims that the hijras of her generation "want to do something different. We want to tell others about our lives so that they can understand us. And we too want to live like those around us" (47). As an activist, "I live on hope. Despite the many challenges, I still persist. Although I often wonder if I am chasing a fading rainbow" (235). Above all, they want to live with dignity.

\section{WORKS CITED}

BANDYOPADHYAY, MANOBI \& JHIMLI MUKHERJEE PANDEY (2017). A Gift of Goddess Lakshmi. New Delhi: Penguin Books.

BENTO, BERENICE (2006). A Reinvenção do Corpo: Sexualidade e Gênero na Experiência Transexual. Rio de Janeiro: Garamond Universitária.

--- (2017a).Transviad@s gênero, sexualidade e direitos humanos. Salvador: EDUFBA. 
--- (2017b). "O Avesso da Tristeza: Luta e Resistência em João Nery", In: Dánie de Jesus et al (ed). Estudos sobre Gênero: Identidades, Discurso e Educação: Homenagem a Jõao W. Nery. Campinas: Pontes Editores: 15-29.

BILL NO. 210 OF 2016.

$<$ http://www.prsindia.org/uploads/media/Transgender/Transgender\%20Persons\%20Bill, \%202016.pdf $>$ accessed 21 August 2017.

BUTLER, JUDITH (2012). Gender Trouble. New York: Routledge.

CHAKRAVARTI, UMA (2013). Gendering Caste through a Feminist Lens. Calcutta: Stree.

DUTTA, ANIRUDDHA, \& RAINA ROY (2014). "Decolonizing Transgender in India", Transgender Studies Quarterly, Vol. 1, N 3, 320-336. https://doi.org/10.1215/23289252$\underline{2685615}$

FOUCAULT, MICHEL (1988). História da Sexualidade I: A Vontade de Saber. Rio de Janeiro: Graal.

--- (1995) A Arqueologia do Saber. Rio de Janeiro: Foresense Universitária.

LAL, VINAY (2005). Of Cricket, Guinness and Gandhi: Essays on Indian History and Culture. New Delhi: Penguin Books.

LESSA, JORDHAN (2014). Eu trans: a alça da bolsa, relatos de um transexual. Rio de Janeiro: Metanoia Editora.

MENON, NIVEDITA (2012). Seeing Like a Feminist. New Delhi: Zubaan/Penguin Books.

MOGLI, VYJAYANTI VASANTA (2016). "Over Two Years After Landmark Judgment, Transgender People Are Still Struggling", The Wire, 5 May. $<$ https://thewire.in/35978/over-two-years-after-landmark-judgment-transgender-peopleare-still-struggling/> accessed 21 August 2017.

MOIRA, AMARA (2016). E se eu fosse puta. Sorocaba: Hoo Editora.

NERY, JOÃO (2011). Viagem solitária. Memórias de um transexual 30 anos depois. Rio de Janeiro: Leya Brasil.

VENKATESAN, J (2014). "Legal recognition for transgenders", The Hindu, 16 April. $<$ http://www.thehindu.com/todays-paper/legal-recognition-fortransgenders/article5916955.ece> accessed 21 August 2017.

REDDY, GAYATRI (2005). With Respect to Sex. Chicago: The University of Chicago Press.

REVATHI, A (2010). The Truth about Me: A Hijra Life Story. Translated by V. Geetha, New Delhi: Penguin Books. 
--- (2012). Our Lives Our Words: Telling Aravani Life Stories. Translated by A. Mangai, New Delhi: Yoda Press.

--- (2016). A Life in Trans Activism. Translated by Nandini Murali, New Delhi: Zubaan.

SEMMALAR, GEE IMAAN (2014). "Unpacking Solidarities of the Oppressed: Notes on Trans Struggles”, Women’s Studies Quartely, Vol. 42, No 3-4, Fall/Winter: 286-291.

TELLIS, ASHLEY (2012). "Disrupting the Dinner Table: Re-thinking the 'Queer Movement' in Contemporary India”, Jindal Global Law Review, Vol. 4, No 1, August: 142-156.

TRIPATHI, LAXMI NARAYAN (2015a). Me Hijra, Me Laxmi. Translated by R. Raj Rao and P. G. Joshi, New Delhi: Oxford University Press.

--- (2015b). Interview by Shanoor Seervai. "Laxmi Narayan Tripathi: India's Third Gender The activist on the ancient legacy and contemporary struggles of hijras", Guernica, 16 March. < https://www.guernicamag.com/indias-third-gender/> accessed 21 August 2017.

--- \& POOJA PANDE (2016) Red Lipstick: The Men in My life. New Delhi: Penguin Viking.

VANITA, RUTH, \& SALEEM KIDWAI (eds) (2008). Same-Sex Love in India: A Literary History. Gurgaon: Penguin.

VIDYA, LIVING SMILE (2013). I am Vidya: A Transgender's Journey. New Delhi: Rupa Publications.

--- (2008). Naan, Vidya. Chenai: Kizhakku.

WA THIONG'O, NGŨGĨ (2013). “A Globalectical Imagination”, World Literature Today, Vol. 87, No. 3, May/June: 40-42

Regiane CorrêA DE Oliveira Ramos teaches English at Faculdade de Tecnologia (Fatec) in São Paulo, Brazil. She is the President of Brasil-Índia Associação de Redes de Conhecimento (Brazil-India Knowledge Networks Association). She holds a Ph.D. in English literature from the University of São Paulo, Sao Paulo, Brazil (2016). In 2012-13, she was a CAPES Ph.D. Fellow at the English Department of Jawaharlal Nehru University, New Delhi. Her areas of interest and research are postcolonial studies, de-colonial studies, multi-literacy studies and gender studies. Currently, she is researching about literature on the hijra community of India in the English language. 